\title{
THE DEVELOPMENT OF ETHNO-CULTURAL COMPETENCE OF THE STUDENTS IN NON-LANGUAGE HIGH SCHOOL
}

\author{
Elena K. Kuzmina \\ Kazan Federal University, Kazan, Tatarstan, Russia \\ Olga A. Danilova \\ Kazan Federal University, Kazan, Tatarstan, Russia
}

\begin{abstract}
The article deals with the problem of ethno-cultural component of foreign language learning in a high school. Being the link between the past and the future, ethno-cultural education promotes man of culture formation and a tolerant personality capable for ethnical self-determination, and having qualities of a citizen. The purpose of this article is to identify and justify social and pedagogical effects of students' ethno-cultural education. To test the hypothesis there were used complementary to each other relevant methods: theoretical methods - an analysis of pedagogical literature, various materials on ethno-cultural, multilingual and cultural education, ethnolingvodidactics, studies on the subject under the research; empirical methods - the observation, identification and registration of pedagogical experiment, interview and testing, discussions and examination, and the results of academic and extracurricular activities of students. The results of sociological studies in Kazan Federal University are used in the given article. In the conclusion the authors give the practical recommendations for improving the effectiveness of the formational process of ethno-cultural competence.
\end{abstract}

Keywords: ethno-cultural component, foreign language, high school education, ethnolingvodidactics.

\section{INTRODUCTION}

In the Republic of Tatarstan, as in a multinational republic, the ethno-cultural component is very important. Therefore, we believe it is important to instill in students a love for the native land, respect and understanding of another culture and religion, traditions of other peoples, especially in multinational Tatarstan, to cultivate tolerance and hospitality as currently required qualities.

Only student, who knows and loves the national culture, can relate its own culture with the culture of the people whose foreign languages is studied. The necessity of learning foreign languages in close liaison with ethno-cultural component, is dictated by the fact that the understanding of other cultures is possible only on the basis of knowledge of own national culture. The ability to navigate the different types of cultures, to interpret adequately phenomena and facts of native and foreign language cultures, to compare and draw conclusions about the general and specific system of cultural values of comparative communities, to get through the difficulties during the intercultural dialogue, to discuss private and global problems of humanity - all this is the heart of ethno-cultural competence of the students, the formation of which is one of the leading aims in language education at the present stage.

The Republic of Tatarstan is a subject of the Russian Federation. The Declaration of State Sovereignty of the Republic was signed on the 30th of August, 1990. The names "Republic of Tatarstan" and "Tatarstan" are equivalent.

The official languages are Tatar and Russian.

Tatarstan is one of the largest socio-economic, scientific and political centres of the Volga Region. It is located at the centre of the Russian Federation. It connects East and West, North and South of the country. The republic has rich natural resources and a developed industry. The industrial complex is very important in the republic. 
Tatarstan is a multireligious republic. During its history Tatarstan has accumulated the richest experience of peoples of various nationalities, ethnic and religious groups. More than 100 nationalities live friendly in the republic. The important national values are tolerance, consensus and compromise.

Theoretical understanding of the unique experience of teaching foreign languages and cultures in a multilingual and multicultural environment carried out on the basic principles of etnolingvodidaktics - a new direction in methodical science, reasonable and headed by the doctor of pedagogical sciences, professor N.V. Baryshnikov (2010, 2011, 2014).

The essence of etno- and multiculturalism in education as an issue is disclosed in various educational researches. For example, I.G. Kondratieva and the others discussed the general psychological conditions that characterize the process of poly-cultural education in non-language high school; L.V. Kuznetsova and the others identified and justified of social and pedagogical effects of schoolchildren's ethno-cultural education; D.R. Sabirova consider the problem of ethnocultural component of foreign-language education with innovative method of teaching at secondary school; O.I. Kolomok and A.S. Krapivensky studied the formation of student's ethno-cultural competence in colleges which must be realized as a balanced complex of educational and extracurricular activities.

The development of ethno-cultural competence of the students in non-language high school increases significantly under the following pedagogical conditions:

- a balanced complex of educational and extracurricular activities;

- qualified pedagogical stuff;

- continuously implement ethno-cultural topics in every lesson to encourage students to become active learners who regulate their own learning through reflection and evaluation.

\section{MATERIALS AND METHODS}

The tasks of the research are:

1) to improve level of knowledge of students in the area of historical and cultural backgrounds of Kazan and Tatarstan

2) to help to understand students some aspects of the socio-economic development of Kazan and Tatarstan

3) to develop creativity and open-minded attitude in discovering the world around

4) to preserve and develop their ethnic culture and traditions

5) to encourage students to understand their native country

To test the hypothesis there were used complementary to each other relevant methods:

- Theoretical methods - an analysis of pedagogical literature, various materials on ethnocultural, multilingual and cultural education, ethnolingvodidactics, studies on the subject under the research;

- Empirical methods - the observation, identification and registration of pedagogical experiment, interview and testing, discussions and examination, and the results of academic and extracurricular activities of students.

The place for the experiment was granted by the Institute of International Relations, History and Oriental Studies of Kazan (Volga Region) Federal University in the Institute of Fundamental Medicine and Biology and the Institute of Geology and Petroleum Technologies. The study consisted of three phases.

First phase - analytical: we formed the hypothesis; set a goal and identified research problems; developed a technique experimental work; carried out preparations for experimental work (there were selected control groups among students); determined the duration of the experiment; developed specific techniques; 
determined the signs by which we could judge about the changes in the experimental facility under the influence of appropriate pedagogical influences.Second phase - practical, was devoted to the research work of students for preparing reports about some historical and cultural facts about Kazan and Tatarstan; to involve students into discussions; to form system of students' knowledge about culture, history, nature and traditions of homeland which will form such personality as creative and open-minded in discovering the world around.

Third phase - analytical, was dedicated to the development and use of results in future work.

We had four groups of fifteen students (totally sixty students) students of Institute of Fundamental Medicine and Biology and the Institute of Geology and Petroleum Technologies.

In the process of training the students, participating in the experiment, formation of ethno-cultural competence through training activities in its basic part was made by preparing 3-5 minutes speech (report) by student about any socio-cultural aspect of life of Kazan as a capital of Tatarstan.

Theoretical material of the course was presented in reports and there are works on texts and discussions about actual problems of the history, culture and modernity of Tatar culture. In studying the history of Tatar culture, the particular attention was given to the current state of positive interaction of ethno-cultural communities.

In addition to traditional forms of work (lectures, discussions) innovative educational technologies were used: practical training in the form of guide tour on foot made by students.

Analysis of the questionnaire data, surveys and interviews at the beginning of the experiment showed the real picture of the students' development, in particular assimilation of ethno-cultural competence was represented by three levels:

low - students don't know much about Kazan and Tatarstan; they consider such notions as the native country, dignity, honour and friendship only as relicts of the past; such students don't have wise international policy.

medium - students know some facts about Kazan and Tatarstan; they are ready to create a positive example of a person who obtain ethno-cultural competence; they are ready to get together and socialize, improve their knowledge, engage more actively in their culture and introduce the Tatar culture to others.

high - students know about glorious and unique history of their homeland - multinational Tatarstan, the best traditions of the past and its future prospects; they can fluently discuss current socio-economic, cultural and present daily life of the republic; they show strong pride of their home; students express hospitality as one of the traditional features of the republic; they are always glad to meet foreigners, visitors and guests and happy to create a relaxing and friendly atmosphere for them; such students increase the authority, prestige of Tatarstan as an international republic.

\section{RESULTS}

This experiment can be relevant in high school, because at this stage there is:

1) improvement of verbal interaction skills;

2) expansion of subjects;

3) scope of dialogue and situations for active use of foreign language learners;

4) expansion of communicative vocabulary of students, and activation of the use of communicative and meaningful grammatical constructions;

5) growth of culture-oriented linguistics and socio-cultural knowledge through their real inclusion in the "live" communication; 
6) creation of motivation for further improvement in foreign language skills.

Integration of Tatar culture with the study of a foreign language can be carried out in two courses.

1. The first course is due to the inclusion of local historical information from different subject (history, geography, the Tatar language and literature, art and the history of science and philosophy) in a program of learning a foreign language.

This integrative approach is appropriate to expand the horizons of students; to concentrate the material around a specific theme; to improve language capabilities of students.

Thematic way to mastering local lore information helps to organize the information received from the different sciences and to create a complete picture of the history and contemporary life of Tatarstan.

2. The second direction in the implementation of the ethno-cultural component in the study of a foreign language is expressed in a creative reinterpretation of regional studies obtained information, the ability to specify and analyze historical and contemporary trends of development of the republic. With the help of foreign language students learn to reflect, to compare, to offer their solution of urgent social problems. This trend is most effective when we consider the current economic situation, social, cultural, youth, and moral aspects of life of the republic.

Discussed courses are intended to contribute to a persistent motivation for the dialogue of cultures, enhancing the emotional impact on the local history information of students, updating of knowledge about the life of Tatarstan and its ability to constructive thinking.

An important feature of humanistic pedagogy is the age and intellectual access to the material under study for students. Following the basis of age, we distinguish 3 levels of assimilation of local history information on the foreign language lessons:

1) Emotional and cognitive;

2) Cognitive-search;

3) Social and personal.

The materials of two sociological studies made by the professor stuff of the Institute of International Communication, History and East studies of KFU; we used it in the given research:

"Research of ascertaining stage" (September, 2015).

On this stage we investigated the level of ethno-cultural competence, existed before forming stage of the experiment on the students of Institute of Fundamental Medicine and Biology and the Institute of Geology and Petroleum Technologies, conducted by us in order to maximize this competence;

On this stage $75 \%$ of students showed low level of knowledge about Kazan and Tatarstan; 20\% showed medium level and only $5 \%$ showed high level.

"Research of post-forming stage" (end of December, 2015).

On this stage we investigated the level of ethno-cultural competence of students of two institutes, mentioned above, occurred after our experiment.

On this stage $80 \%$ of students showed high level of knowledge about Kazan and Tatarstan; 20\% showed medium level.

According to different positive results we can make conclusion that our experiment was effective. Students got new knowledge which can be used in practice during the communication with people from different cultures. We can be sure that students who know and respect their own culture will be tolerant and pleased to other nations. 


\section{DISCUSSIONS}

Current requirements for the introduction of an ethno-cultural component of the maintenance associated with the need to solve the most complicated problem dialectically contradictory to the initiation of human knowledge and civilizational values, while ensuring its national identity itself. In this case the main purpose of the implementation of national-regional component in school educational practice advocates education and human learning the basics of the national culture, native language, while its inclusion in the world's common cultural and moral values. However, an ongoing debate about what methods and means for this goal will be achieved, what requirements must be presented to the educational process, in the course of which must form an educational and educational path, taking into account, in addition to the general requirements, individual abilities and features.

\section{CONCLUSION}

The formation of students' ethno-cultural competence in universities must be realized as a balanced complex of educational and extracurricular activities.

The effective part of extracurricular activities can be realized as a guide tours (presented by students).

Pedagogical effects from ethno-cultural education are characterized by the fact that students: understand their role in the life of Tatarstan republic; start forming a stable interest and need for the development of ethnic and cultural values; accumulate the ethno-cultural knowledge; develop a sense of belonging to the history and culture of Tatar people; develop associative thinking based on the perception of the socio-economic development of the republic; creative consistency is formed as a sustainable creative attitude willing to express themselves in a creative work; develop artistic taste, based on national ideals.

\section{ACKNOWLEDGMENTS}

The research (work) is performed according to the Russian Government Program of Competitive Growth of Kazan Federal University.

\section{REFERENCES}

Барышников Н.B. Myths and Reality about Intercultural Dialogue in Foreign Language Teaching//Journal of International Scientific Publication: Language, Individual and Society, Volume 4, Part 1. - Бургас, 2010. - C. 144-151. - ISSN 1313-2547 Published at : http://www.science-journals.eu

Барышников Н.B. Socio-political Background of cross-cultural communication //Journal of International Publications Language, Individual and Society Vilume. - 5. - Part 5. - ISSN 1313-2547, 2011. European Union. - Publeshed at http://www.science-journals.eu

Барышников Н.В. Плюсы и минусы межкультурной коммуникации (статья)//Иностранные языки в современном образовании: парадигмы исследований и модели обучения «Лемпертовские чтения XVI». - Пятигорск: ПГЛУ, 2014. - С. 3-9.

Oksana I. Kolomok and Anatoly S. Krapivensky Formation of Student's Ethno-Cultural Competence in Colleges: Informational Security Aspects http://www.idosi.org/ejas/5(6)13/2.pdf

Liudmila V. Kuznetsova Tatyana N. Petrova Vladimir N. Ivanov Galina G. Tenyukova Igor V. Kozhanov Natalya S. Morova Sergey P. Yakovlev Social and Educational Effects (Dominants) in Schoolchildren' Ethno-cultural Education Mediterranean Journal of Social Sciences MCSER Publishing, Rome-Ital http://www.mcser.org/journal/index.php/mjss/article/viewFile/6026/5792

Kondrateva I.G. The Development of the Student as a Person of Culture in the Context of Multicultural Education in Non-Language High School by Means of a Foreign Language // Mathematics Education. 2016, 11(1). - P. 57-69

Sabirova D.R. Republic of Tatarstan: priorities of school foreign language education //EDULEARN15 Proceedings 7th International Conference on Education and New Learning Technologies 2015, Barcelona, Spain. - P. 7865-7869.

Sabirova D.R. Ethnocultural Component of Foreign-Language Education: Innovative Mode // Mediterranean Journal of Social Sciences. - 2015. - Vol 6, No 3 S1 . - P. 356-362.DOI: 10.5901/mjss.2015.v6n3s1p362 